\title{
Spotting Bubbles: \\ A Two-Pillar Framework for Policy Makers
}

\author{
Bradley A. Jones ${ }^{1}$ \\ International Monetary Fund, United States of America \\ bjones@imf.org
}

Received: 5 March 2016 / Revised: 12 July 2016 / Accepted: 15 July 2016 / Published online: 29 July 2016

\begin{abstract}
In the aftermath of the global financial crisis, the issue of how best to identify speculative bubbles remains in flux. This owes to the difficulty of disentangling irrational investor exuberance from the rational response to lower risk, based on price behavior alone. In response, I introduce a twopillar (price and quantity) approach for financial market surveillance. While asset pricing models comprise a valuable component of the surveillance toolkit, risk taking behavior, and financial vulnerabilities more generally, can also be reflected in subtler, non-price terms. Though policy makers will always encounter uncertainty when attempting to measure imbalances in financial markets, 'perfect should not be the enemy of the good.' In this spirit, the framework in this paper seems to capture some of the stylized facts of asset booms and busts, and thus could offer policy makers a practical guide as to when to consider leaning against the wind.
\end{abstract}

JEL classification: E44, F37, G12, G15, G18

Keywords: asset bubbles, asset pricing, market efficiency, macroprudential policy

\section{INTRODUCTION}

Financial history reads in many respects as a history of booms, bubbles and busts. The Dutch Tulip Mania (1634-1637), the French Mississippi Bubble (1719-20), the South Sea Bubble in the United Kingdom (1720), the first Latin American debt boom (1820s), and railway manias in the United Kingdom (1840s) and United States (1870s) are all notable early examples. ${ }^{2}$ In the past century, no busts have been more devastating than the Great Depression ushered in by the collapse of world stock markets in 1929. Over the past few decades, the Japanese Heisei bubble in the late 1980s, the various emerging market booms and busts in the 1980s and 1990s, and the equity mania in the late 1990s, offer examples of speculative frenzies gone awry. The threat to financial stability posed by large asset price movements has come into sharper focus over the past decade as the boom during the Great Moderation gave way to the collapse in global credit, real estate, and equity markets. Most recently, questions have been raised as to whether the prolonged use of unusually accommodative monetary policies may be fermenting another asset price bubble.

Corresponding author Bradley A. Jones. Email: BJones@imf.org. Tel +1 202-623-9914. International Monetary Fund, Monetary and Capital Markets Department, 700 19th street NW, Washington D.C., USA.

2 As with many aspects of the speculative bubble literature, it should be noted that there remains considerable disagreement among scholars as to which of these episodes actually represent bona-fide bubbles. 
Much of the debate over the existence and implications of speculative bubbles stems in the first instance from disagreement as to their measurable properties: the term "bubble" has been widely used to mean very different things. ${ }^{3}$ Bubble models typically emphasize the self-fulfilling nature of expected future price changes based on the concept of 'resale optionality.' This enables asset prices to be decomposed into a rational intrinsic yield component (based on discounted future cash flows), and an irrational bubble component (based on expectations of future capital gains independent of fundamentals). Other researchers have focused upon the broader social dimensions of bubbles, with their tendency to engulf members of society who typically have little interest in financial matters (Mackay, 1841; Keynes, 1936; Kindleberger, 1978; Chancellor, 2000; Shiller, 2000a; Bonner and Rajiva, 2007; Reinhart and Rogoff, 2009; and Akerlof and Shiller, 2009). ${ }^{4}$ Yet definitional ambiguity and inference problems have long plagued formal studies of speculative bubbles. Distinguishing irrational investor exuberance from the rational response to lower perceived risk is made difficult in real time by numerous issues, not least that it can only be known with absolute certainty ex-post whether the optimistic ex-ante projections embedded in asset prices were in fact justified.

Though much of the post-crisis literature has focused, understandably, on the role of credit growth in fermenting asset bubbles, the next major threat to financial stability may well take a different form. Moreover, as capital markets continue to expand in scale and scope, there are reasons to expect their dynamics to increasingly capture the attention of policy makers (Haldane, 2014; Stein, 2014; Feroli and others, 2014; Jones, 2015). In response, I introduce a simple two-pillar approach to bubble surveillance, based on both price and quantity data in the capital markets. ${ }^{5}$ Though by no means a conclusive solution to the age-old difficulties of crisis prediction, the framework appears to offer promise in capturing some of the stylized facts of asset booms and busts: some of the largest in history have been associated not just with below average risk premia (captured by the 'pricing pillar'), but also with unusually elevated patterns of issuance, trading volumes, fund flows, and survey-based return projections (i.e., the 'quantities pillar'). The ability to cross-reference signals from both pillars may give policy makers a richer understanding of the dynamics of asset price cycles and the threats they pose (if at all) to economic stability.

The analysis proceeds as follows. A synthesis of measurement and inference issues that arise in the identification of speculative bubbles is presented in Section 2. Section 3 outlines the contours of the two-pillar approach, drawing upon past asset boom and bust episodes to demonstrate the concept. Concluding remarks and suggestions for future research are presented in Section 4.

\section{LITERATURE REVIEW - BUBBLE MEASUREMENT AND INFERENCE ISSUES}

Speculative bubbles are intuitively recognized to represent situations where market prices significantly exceed the level dictated by fundamentals. ${ }^{6}$ Yet broad agreement as to the properties of speculative bubbles has remained elusive virtually ever since the concept of speculation has been invoked. These have not been debates over semantics, but rather quite fundamental issues with important policy implications. For instance how large must be the deviation of prices from those suggested by a fundamental-based model in order for it to be considered 'speculative' or

\footnotetext{
References to "bubbles" throughout this paper are made in the general sense: (i) of an asset price so high that no reasonable (probabilityweighted) future scenario for fundamentals could justify it, and (ii) where the expectation of future short-term price gains drives explosive selffulfilling increases in prices (and possibly transaction volumes). Section 2 discusses measurement issues in more detail.

4 It is not uncommon for policy makers to monitor anecdotal information along these lines. For instance, to complement their formal quantitative analysis of home price dynamics, the Reserve Bank of Australia has been known to monitor the number of property seminars held by finance companies targeting retail investors.

This two-pillar approach is analogous to the European Central Bank's (ECB) approach to maintaining price stability by cross-checking both real and monetary developments.

Under this general concept, bubbles could include episodes where prices do not rise at all — for instance where (expectations of) fundamental values collapse but prices are unchanged or decline only modestly. Alternatively, a 'negative bubble' represents a situation where asset prices far undershoot the level implied by fundamentals. For the purposes of this paper and consistent with much of the related literature, our discussion of asset booms and bubbles refers to episodes where prices are rising rapidly (in absolute terms and relative to fundamentals).
} 
'irrational'? ${ }^{7}$ And for how long must the discrepancy between model-predicted and observed prices persist? Reflecting the so-called 'joint hypothesis problem,' how do we know a model of fair value, upon which the determination of a bubble is made, is in fact correctly specified in the first instance? Offering a related defense of his seminal efficient markets asset pricing paradigm, Eugene Fama asserted,

"I don't even know what a bubble means. These words have become popular. I don't think they have any meaning ... They have to be predictable phenomena ... It's easy to say prices went down, it must have been a bubble, after the fact. I think most bubbles are twenty-twenty hindsight. Now after the fact you always find people who said before the fact that prices are too high. People are always saying that prices are too high. When they turn out to be right, we anoint them. When they turn out to be wrong, we ignore them. They are typically right and wrong about half the time... I didn't renew my subscription to the The Economist because they use the word bubble three times on every page. People have become entirely sloppy."8

Theoretical studies have often focused upon the extrapolation of recent capital gains into the expectation of future capital gains, based on the concepts of 'resale optionality' and the selffulfilling nature of expected future price changes. Analytically, this allows for a clean delineation between the rational and irrational component of asset prices. ${ }^{9}$ For instance, Hirshleifer (1977) suggests speculation refers to the purchase (sale) of a good for later re-sale (re-purchase), rather than for use, in the hope of profiting from an intervening price change. Harrison and Kreps (1978) suggest investors exhibit speculative behavior if the right to resell a stock makes them willing to pay more for it than they would pay if obliged to hold it forever. On this basis, an asset bubble exists where investors make a purchase only if they have the ability to subsequently sell the asset at some future date. Kindleberger (1987) defines a speculative bubble as a sharp rise in price of an asset or a range of assets in a continuous process, with the initial rise generating expectations of further rises and attracting new buyers - generally speculators, interested in profits from trading in the asset rather than its use or earning capacity. Stiglitz (1990) defines a bubble where the reason that the price is high today is only because investors believe that the selling price will be high tomorrow - when 'fundamental' factors do not seem to justify such a price. Flood and Garber (1994) categorize a bubble where the positive relationship between price and its expected rate of change implies a similar relationship between price and its actual rate of change. In such conditions, the arbitrary, self-fulfilling expectation of price changes may drive actual price changes independently of market fundamentals. Shiller $(2003$, pp. 35, 38) describes a bubble in behavioral terms where irrational investors are attracted to an investment because "rising prices encourage them to expect, at some level of consciousness, more price increases. A feedback develops - as people become more and more attracted, there are more and more price increases ... the amplification mechanisms that make a bubble grow strong are just that price increases beget more price increases, through human psychology."

From a different perspective, Siegel $(2003$, p. 14) states formulaically that "a period of rising (or falling) prices in an asset market can be described as a bubble (or negative bubble) at time $t$ if it can be shown that the realized return of the asset over a given future time period, that time period defined by the duration of the asset, can be shown to be inconsistent, i.e. more than two standard deviations from the expected return, given the historical risk and return characteristics of that asset at time $t$." This is an ex-post measure where the real time identification of irrational optimism (or pessimism) is impossible - the presence of a bubble can only be established once

Black (1986) notes that a market could still be considered efficient even if prices deviated in a range of plus 200 percent and minus 50 percent of fundamental value.

8 Cassidy (2010).

The fundamentally-derived cash flow yield is a stationary process, in contrast to the irrational bubble component which is non-stationary. 
fundamental data have been realized over the maturity of the asset. In acknowledging there will almost always be ex-ante and ex-post disagreement about the objective measurement of bubbles, Asness (2014) concludes more generally that to have content, the term should indicate a price that no reasonable future outcome can justify.

Other sweeping historical analyses have emphasized the predominant feature of speculative asset bubbles as their tendency to draw in members of the general public who are typically aloof in monetary matters. In other words, bubbles can be distinguished from other episodes through their broader impact on society. ${ }^{10}$ Yet as colorful as these socio-behavioral descriptions might seem, an obvious limitation is they are not amenable to formal testing.

Empirical tests of speculative bubbles, including those assessing early warning indicators in the context of financial crises, are forced to contend with other difficult measurement and inference issues. In setting threshold levels for asset price misalignments, policy makers have to balance the tradeoff between false negatives and false positives (see Kaminsky and others, 1998; Alessi and Detken, 2009; and Gerdesmeier and others, 2009). If thresholds are set too high, this will increase the likelihood of failing to predict subsequent busts (Type I errors), while setting them too low can come at the cost of incurring frequent warnings of impending busts that do not materialize (Type II errors). Other complications arising from speculative bubble testing include the problems of small sample sizes (dealing with relatively rare events), the stability of estimated coefficients (in vs. out of sample), and quantitatively accounting for the pervasive irrational behavioral/social phenomema that are emphasized in descriptive accounts of speculative manias. ${ }^{11}$

Broadly speaking, formal tests of speculative asset price bubbles are plagued by estimation and measurement limitations to such a degree that they achieve little of substance in advancing the policy debate over the existence of bubbles in real time - the domain in which policy makers operate. As Gurkaynak, (2005, p. 27) concludes, "Bubble tests do not do a good job of differentiating between misspecified fundamentals and bubbles. This is not only a theoretical concern: For every test that 'finds' a bubble, there is another paper that disputes it ... The bubble tests teach us little about whether bubbles really exist or not."

\section{METHODOLOGY AND RESULTS - A TWO PILLAR FRAMEWORK TO OPERATIONALIZE BUBBLE SURVEILLANCE}

The difficulties associated with identifying asset bubbles in real time suggests a need for policy makers to survey and cross-validate information from a variety of approaches and metrics. Unusually stretched asset prices might reflect rationally lower compensation for risk, the limits to arbitrage, or irrational behavioral errors. It is unlikely any single variable or model specification will ever be able to offer irrefutable evidence, in real time, that an irrational bubble is in progress - by definition, bubbles can only be identified with complete certainty ex-post. Without the benefit of hindsight to inform their real time assessments, policy makers need to rely on a diverse and timely suite of measures to highlight the accumulation of financial vulnerabilities and concomitant threats to financial stability. It is in this context that supplemental non-price data might help provide authorities with a richer, more nuanced understanding of risk taking

\footnotetext{
10 In an early example, Mackay (1841) states of the seventeenth century Dutch Tulip Mania, "Nobles, citizens, farmers, mechanics, seamen, footmen, maid-servants, and even chimney-sweeps and old clotheswomen dabbled in tulips." The editorial of the New York Herald wrote in June 1857 that the U.S. railway boom appeared to "infect all classes of society - the country merchant is becoming a city stockjobber, and the honest country farmer has gone off among the gamblers in western land" (Sobel, 1968, p. 96). As Kindleberger (1978, p. 13) points out in his classic study of speculative manias: "There is nothing so disturbing to one's well being and judgment as to see a friend get rich. When the number of firms and households indulging in these practices grows large, bringing in segments of the population that are normally aloof from such ventures, speculation for profit leads away from normal, rational behavior to what has been described as a mania." Shiller (2000a, p. 2) depicts a societywide mania as the spread of "psychological contagion from person to person, in the process amplifying stories that might justify the price increase and bringing in a larger and larger class of investors, who, despite doubts about the real value of the investment, are drawn to it partly through envy of others' successes and partly through a gambler's excitement."

11 Useful summaries of issues encountered in econometric tests of market efficiency and speculative bubbles are presented in Campbell and others (1997) and Gurkaynak (2005).
} 
behavior - potentially enhancing the quality of decision making under uncertainty - even if (as is almost certainly the case) this approach falls short of the proverbial magic bullet solution to the difficulties of crisis prediction. In a pragmatic sense, 'perfect should not be the enemy of good.'

In recognition of these issues, this paper proposes a conceptually straightforward surveillance approach based on two distinct though complementary pillars: one that is price-based (capturing swings in risk premia or required returns), and another that is quantity-based (tracking issuance, transaction volumes, investor fund flows, and investor surveys; see Table 1). Periods where (i) risk premiums have been compressed to abnormally low levels, and (ii) issuance, trading activity, fund flow data, and survey-based return expectations are unusually elevated, are likely to warrant particular attention from policy makers. ${ }^{12}$ Though most of the following analysis is focused on capital markets, this framework can be equally applied to real estate markets. To briefly illustrate, Figure 1 depicts the relationship between the rent/price ratio (i.e., the rental yield, a conventional valuation metric) and transaction volumes in the U.S. housing market over the 1969-2016 period. The U.S. housing bubble of the mid 2000s was notable in that it constituted a three standard deviation event not just in valuation terms, but also in (non-price) quantity terms. As outlined below, asset booms characterized by extremely unusual valuations and turnover present a significant challenge to benign rational-based explanations. More forcefully, one of the paper's main contentions is that they should put policy makers on high alert.

Table 1

A Two-Pillar Asset Bubble Surveillance Framework

\begin{tabular}{cc}
\hline \hline $\begin{array}{c}\text { Pricing Pillar } \\
\text { (top down) }\end{array}$ & $\begin{array}{c}\text { Quantities Pillar } \\
\text { (bottom up) }\end{array}$ \\
\hline Risk Premia (asset valuations) & Quality and quantity of new issuance \\
\hline & Trading volumes \\
\hline
\end{tabular}

Figure 1

The Rent/Price Ratio and Transaction Volumes in the U.S. Housing Market (shown as a z-score)

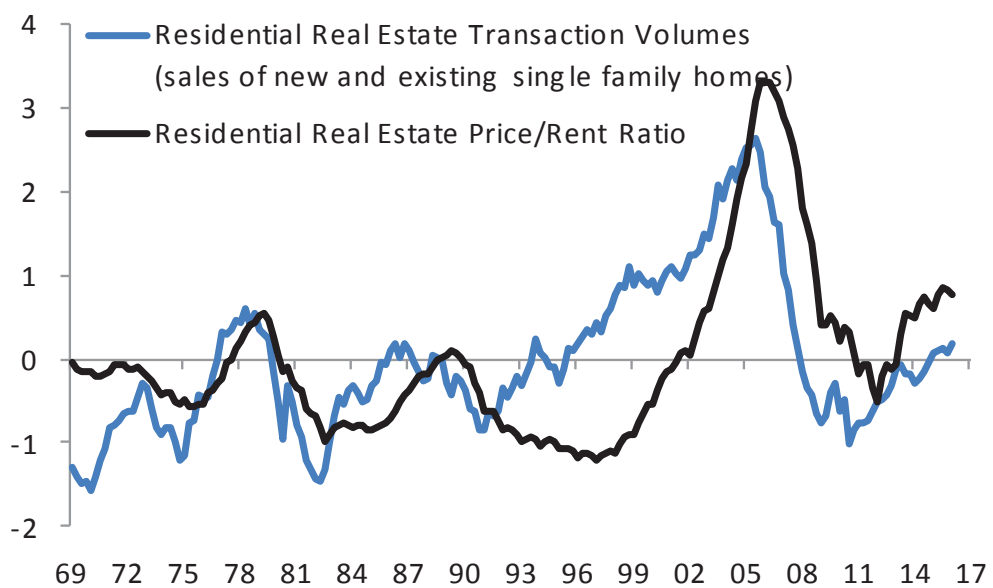

Source: Author's estimates, Census Bureau

Notes: The z-score depicts the number of standard deviations from the mean. The correlation between the two series is 0.54 . Quarterly data from March 1969 - March 2016.

12 This framework is designed to address the 'identification problem.' As to the 'implication problem,' policy makers will need to be guided by other metrics, including but not limited to those assessing the degree of interconnectedness across institutions, credit growth dynamics, potential wealth effects, etc. 


\subsection{The Pricing Pillar}

Over time, the search for explanations of asset price movements has shifted in focus. Early asset pricing theories emphasized the role of changes in expected cash flows as the key driver of variability in asset prices, with discount rates (comprising risk free rates and a risk premium) assumed constant (Fama, 1970). Unusually high valuation ratios could be justified only by expectations of unusually strong cash flow (dividend or rental) growth in the future. However, subsequent research has showed large asset price increases to have been poor predictors of future cash flow growth (see most recently, Cochrane, 2011; and Williams, 2013), with time variation in discount rates now established as the key source of variation in asset returns. As Figure 2 illustrates, while U.S. stock market returns are strongly negatively correlated with contemporaneous changes in risk premia, the link between stock returns and changes in either long-term bond yields or long-term growth expectations is more muted.

Figure 2

Empirical Determinants of Stock Returns

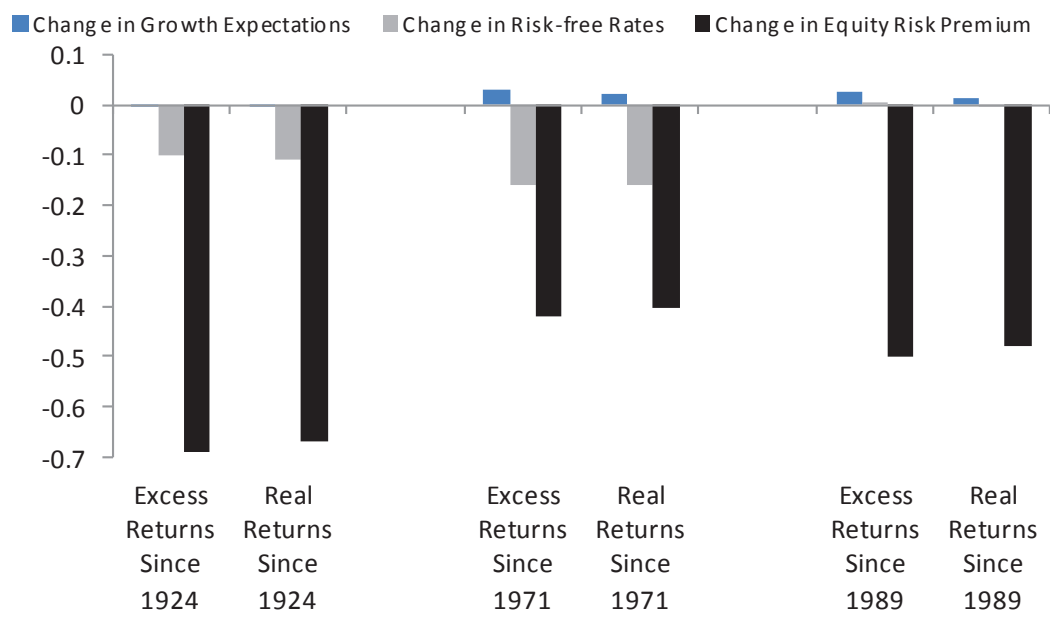

Source: Author's estimates, Consensus Economics.

Notes: The chart depicts the correlation of excess and real S\&P 500 returns to contemporaneous changes in growth expectations, risk-free interest rates, and the equity risk premium. All data are expressed in monthly terms. The sample periods in the above chart reflect the beginning of the data set (1924), the end of the Bretton Woods system of fixed exchange rates (1971), and the beginning of the dataset on survey-based expectations of real growth and inflation compiled by Consensus Economics (1989). Prior to 1989, long-term nominal growth expectations are proxied by a ten year moving average of nominal GDP growth. The risk free rate is the 10 year Treasury yield. The equity risk premium is an average of three separate measures (see Annex).

For surveillance purposes, valuation metrics (ideally based on real-time information) should demonstrate at least some degree of predictive power over subsequent returns. More importantly, they should display unusual behavior preceding large busts. Figure 3 plots the explanatory power of valuation measures over subsequent returns (since 1953) for the major U.S. asset classes (see the $\mathrm{R}^{2}$ from regressions of asset returns over different holding periods on initial levels of valuation). The implied equity discount rate is used to forecast stock returns; the rent/price ratio forecasts returns to housing; the credit spread is used to forecast excess credit returns; and the gap between long term Treasury yields and long-term GDP growth forecasts is used to forecast excess Treasury returns (see Annex for details).

In each asset class, valuations appear to have only modest explanatory power over one year returns, but an increasing degree of explanatory power as the investment holding period extends out to a multi-year basis (i.e., asset returns are noisy in the short-run). ${ }^{13}$ Of greater consequence

\footnotetext{
13 For reasons of data availability, only the results for U.S. asset classes are reported here to demonstrate the concept. Based on the shorter (post-1989) cross-country sample using survey based expectations of long-term growth and inflation, the average $\mathrm{R}^{2}$ (from regressions of realized returns on model-based expected returns) over a one-year holding period for stocks was 0.11 , and 0.18 for bonds. Note this exercise attempts to examine the empirical features of standard return forecasting models - it does not seek to find an 'optimal' model per-se.
} 
is that in the years preceding the three largest crashes in history for each of the major asset classes, ${ }^{14}$ risk premiums (required returns) declined to unusually low levels - around 1 to 2 standard deviations below the long-term average (Figure 4 and 5). Following a bust, they rapidly reverted back to more normal levels over the next two years. Notably, each bust was followed by recession - on average, six months after a peak in the case of equities, eight months for housing, and around two years for credit and Treasuries (Figure 6).

\section{Figure 3}

Valuation-Model based Return Predictability (R2 of valuation models) Across Holding Periods

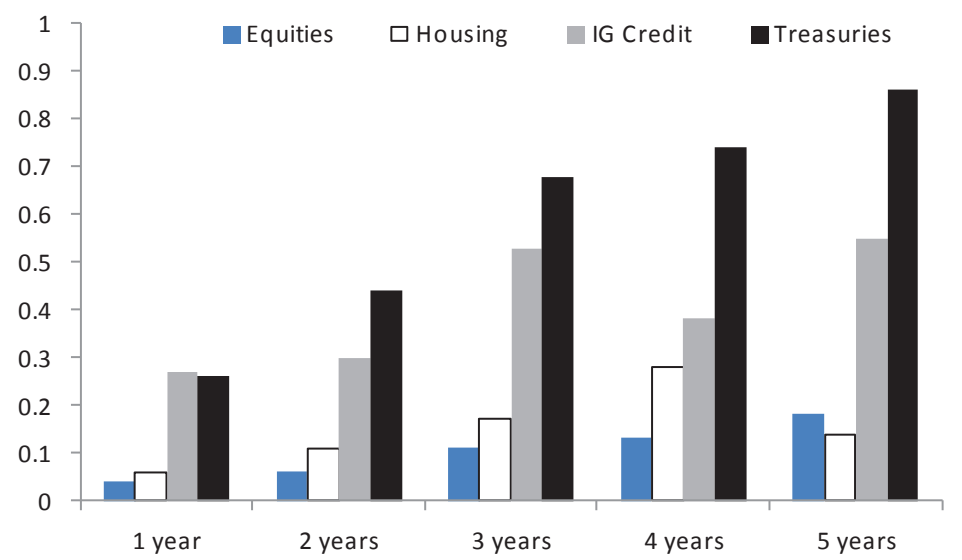

Source: Author's estimates, Haver.

Notes: Chart depicts the $\mathrm{R}^{2}$ from regressions of real (equities and housing) or excess (credit and treasury) returns (measured across different holding periods) on the starting level of valuations for each asset class. Regressions are based on non-overlapping holding periods over the 19532013 sample. In the case of stocks, real returns are regressed on the market-implied real equity discount rate; in the case of housing, real returns are regressed on the rent/price ratio; for investment grade credit, excess returns on BBB credit are regressed on BBB spreads over duration-matched Treasuries; and for Treasuries, 5 year bond returns 5 years forward are regressed on the bond risk premium, measured as the $5 \mathrm{y} 5 \mathrm{y}$ rate less the $5 \mathrm{y} 5 \mathrm{y}$ forward consensus estimate of growth and inflation. See Annex for more details on the valuation measures.

\section{Figure 4}

Risk Premiums (as a Z-score) in the Years Before and After Large Busts

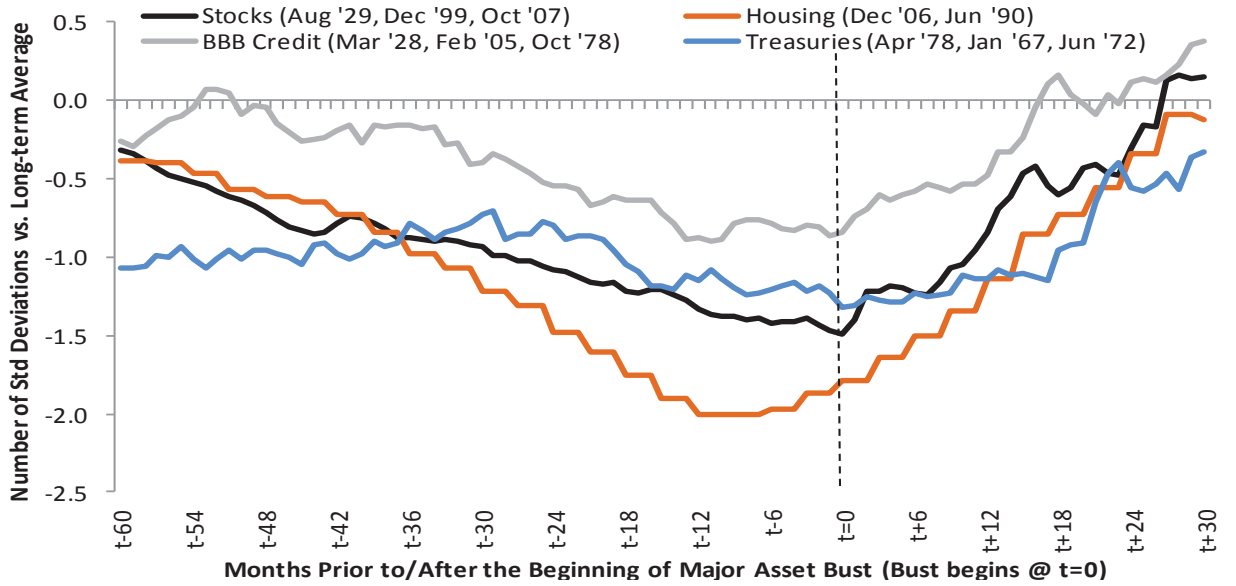

Source: Author's estimates, Haver, Bloomberg.

Notes: Based on the average z-score (depicting the number of standard deviations from the mean) of required returns for the three largest crashes, for each asset class, from five years prior to the commencement of a bust to two and half years after. Dates in parenthesis for each asset class refer to the month in which the bust commenced. Sample period commences in 1924 for stocks and BBB credit, and 1953 for housing and Treasuries, ending in 2013.

\footnotetext{
14 For the purposes of this exercise, crashes were defined as the largest decline in real (equity and housing) or excess (credit and Treasury) total return terms, measured over a three-year observation window (rolling monthly). In order to distinguish separate crash episodes, a new regime is signified whenever the three-year change crosses zero (the series is stationary). Figures are based on the largest three crash episodes, except for housing, which experienced only two episodes of negative three-year real returns between 1953 and 2013.
} 
Figure 5

Risk Premiums (as a z-score) Preceding Large Busts, and Subsequent Asset Returns

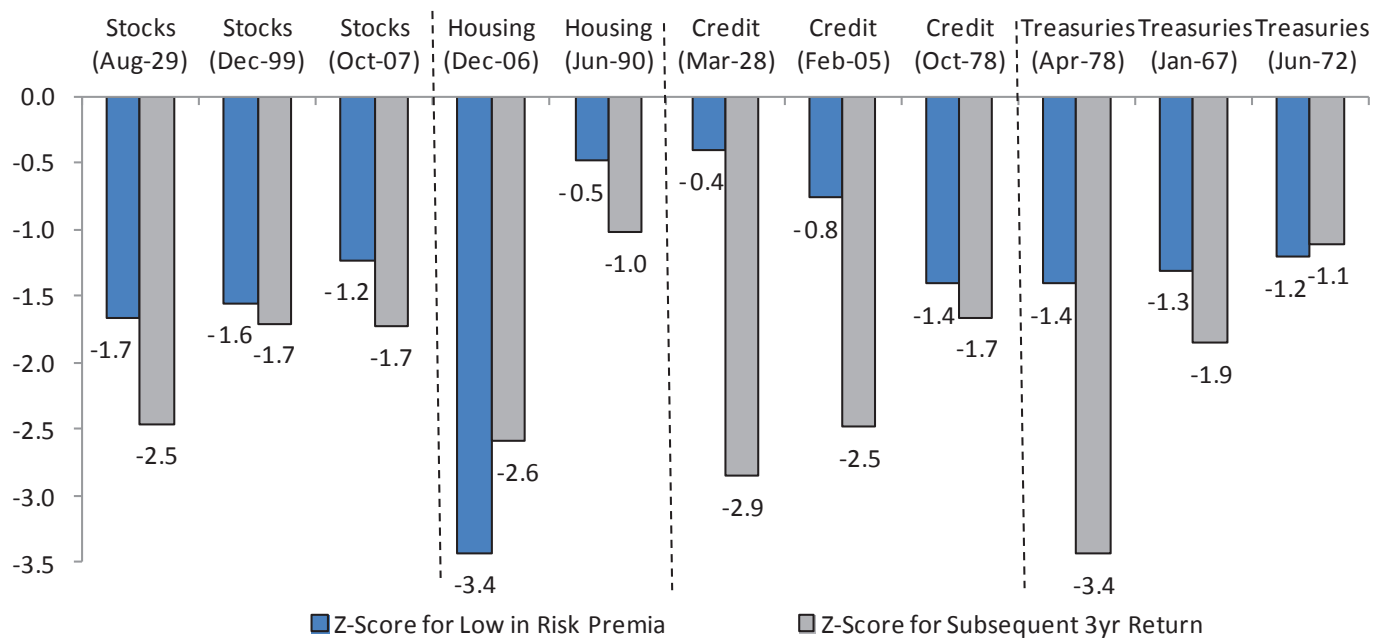

Source: Author's estimates, Haver, Bloomberg.

Notes: The z-score depicts the number of standard deviations from the mean. Dates in parenthesis for each asset class refer to the month in which the bust commenced. Sample period commences in 1924 for stocks and BBB credit, and 1953 for housing and Treasuries, ending in 2013. Asset returns are measured over a three-year observation window, rolled monthly.

\section{Figure 6}

Lead Time between Start of Asset Bust and Onset of Recession (in months)

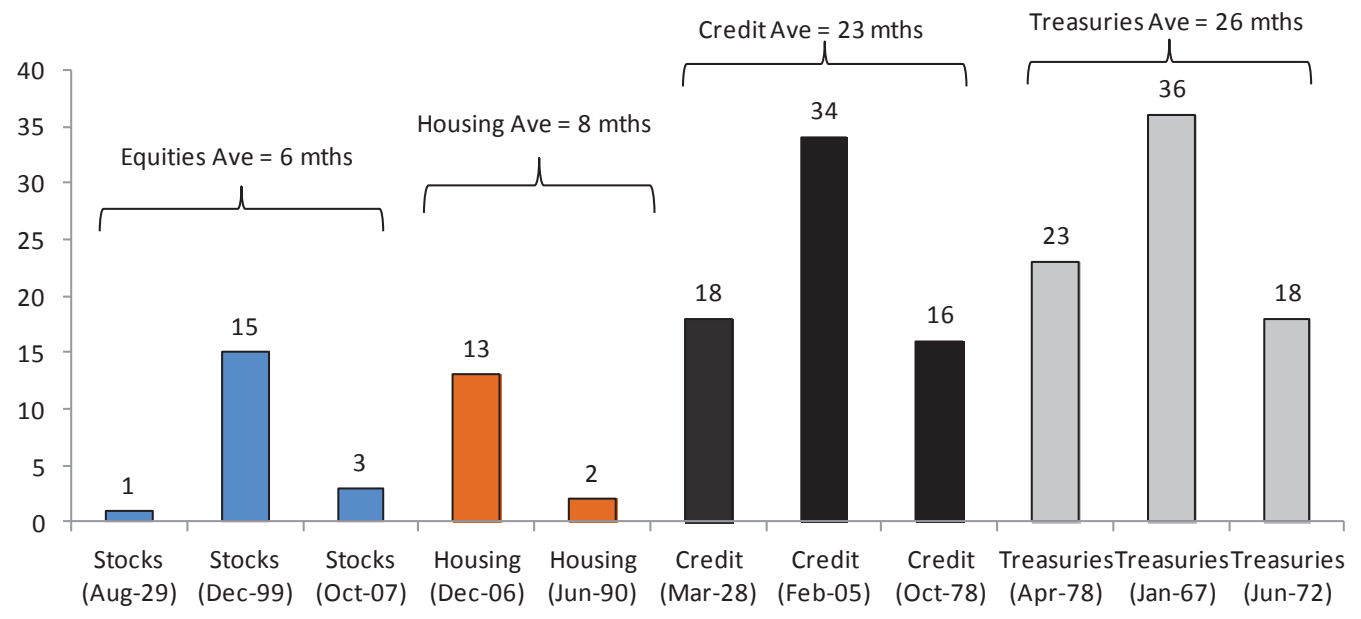

Source: Author's estimates, Haver, Bloomberg.

Notes: Dates in parenthesis for each asset class refer to the month in which the bust commenced. Sample period commences in 1924 for stocks and BBB credit, and 1953 for housing and Treasuries, ending in 2013. Recession dating is based on the NBER classification.

From a broader perspective, policy makers might also glean information as to the generalized environment for risk taking by examining equity and bond valuations across global markets. In this regard, it is interesting to note that based on a sample of 15 developed and 10 emerging markets since 1989, the market-implied real cost of equity (i.e. the required return to hold stocks) for the average country index was more than 1 standard deviation below its historical average prior to the worldwide equity crashes commencing in 2000 and 2008 (Figure 7).${ }^{15}$ In both instances, even the cheapest decile of country equity indices were more expensive than historical averages. World bond markets have not suffered the same type of generalized crash over the post-1989 period,

\footnotetext{
15 Proxies for the equity risk premium provide a similar message. I report results here for the market-implied cost of equity rather than the equity risk premium for two reasons: (i) the cost of equity is a superior forecaster of future stock returns than the equity risk premium; and (ii) stocks are a perpetuity with a duration that is constantly in flux, meaning that deflating the cost of equity by a bond yield at one point in the curve could be akin to comparing apples with oranges.
} 
though it should be noted that the average cross-country measure of risk premia in sovereign bonds (the difference between the 5 year rate, 5 years forward, and consensus estimates for growth and inflation over the same period) is currently close to record lows (Figure 8). ${ }^{16}$ Moreover the most expensive decile of countries on this measure are now almost 3 standard deviations richer than their historical norm.

\section{Figure 7}

Market-Implied Real Cost of Equity across 25 Countries (as a z-score)

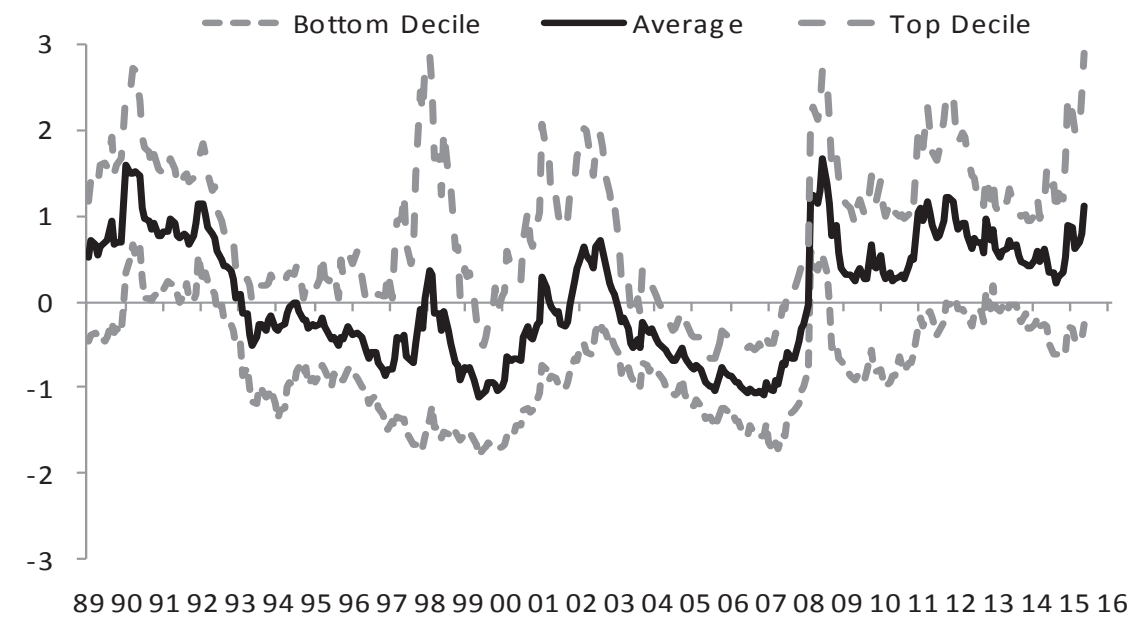

Source: Author's estimates, Consensus Economics, Datastream, Haver, Bloomberg.

Notes: Chart depicts the average, top decile and bottom decline z-score (depicting the number of standard deviations from the mean) for the marketimplied real cost of equity, displayed as an average derived from three models: a cyclically adjusted earnings yield; a single stage perpetuity model; and a multi-stage dividend discount model. See Annex for details. The sample consists of 15 developed and 10 emerging markets, comprising 95 percent of the market capitalization of the MSCI All Country benchmark index. Data from September 1989 - January 2016.

\section{Figure 8}

'Wicksellian' Sovereign Bond Risk Premia across 25 Countries (as a z-score)

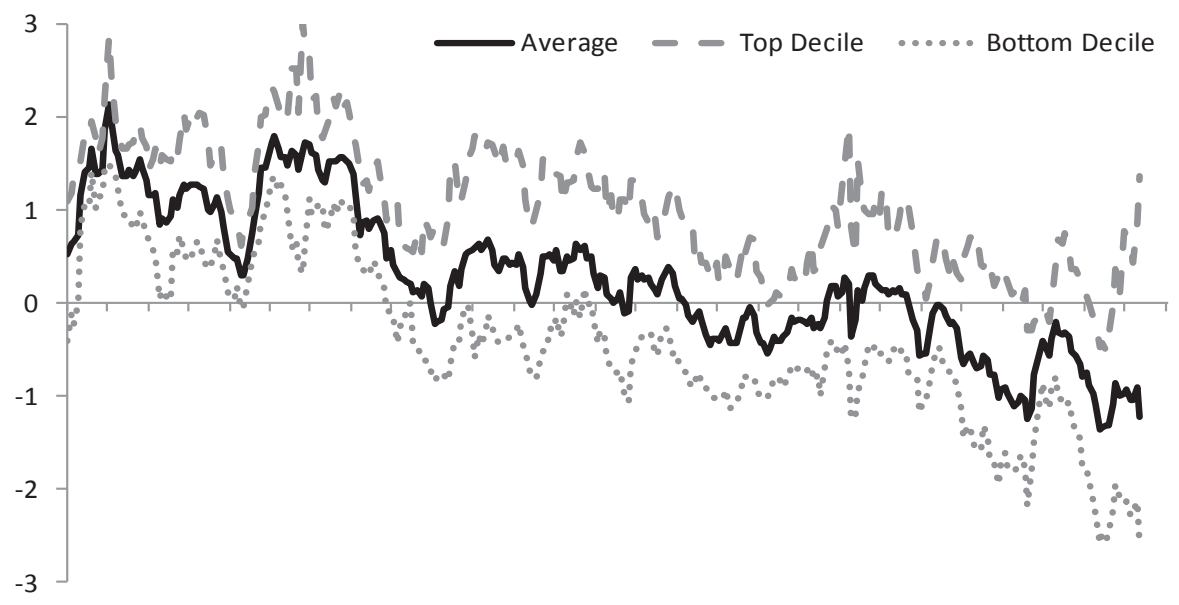

89909192939495969798990001020304050607080910111213141516

Source: Author's estimates, Consensus Economics, Datastream, Haver, Bloomberg.

Notes: Chart depicts the average, top decile and bottom decline z-score (depicting the number of standard deviations from the mean) for the 'Wicksellian' sovereign bond risk premia, measured as the 5 year rate, 5 years forward, minus consensus estimates for growth and inflation over the same period. See Annex for details. The sample includes 15 developed markets and 10 emerging markets, comprising 94 percent of the market capitalization of the Citigroup World Government bond benchmark index. Data from September 1989 - January 2016.

16 A negative 'Wicksellian' bond risk premium suggests bond yields are too low relative to the neutral rate for the economy, as proxied by longrun estimates of growth and inflation. By examining the relationship in long-term forward space, the impact of near-term monetary policy settings is ameliorated. 


\subsection{The Quantities Pillar}

The aforementioned results suggest asset pricing models should comprise a key component of the surveillance toolkit. Nevertheless, risk taking behavior, and financial vulnerabilities more generally, might also be reflected in subtler, non-price terms - beyond what asset valuations alone can signify. Additionally, 'top down' asset pricing models are subject to considerable estimation error: forward looking inputs are unobservable and small changes in discount rates for long duration assets can exert a very large impact on estimates of fair value (recall Figure 1). As such, (non-price) quantity data may have a useful cross-referencing role for the purposes of financial surveillance. ${ }^{17}$ Against this backdrop, the analysis that follows is based on the 'bottom up' information content in: (i) the quantity and quality of capital market issuance; (ii) trading volumes; (iii) investor fund flows; and (iv) investor surveys. This may be the first proposal for a multi-faceted cross-asset 'quantities pillar' to be employed as a supplement to more traditional valuation-based surveillance analysis. ${ }^{18}$ It should be noted however that the absence of lengthy time series and comparable cross country data necessarily makes the following more interpretative than the earlier analysis.

\section{(i) Quantity and Composition of Capital Market Issuance}

The financial crisis of 2008 yielded important insights regarding the information content embedded in the increasing quantity and declining quality of capital market issuance. Credit markets are particularly amenable to scrutiny in non-price terms as implicit leverage, subordination, illiquidity, and a paucity of investor protection features allow investors to take on risk in ways that might transcend conventional measurement through spreads alone. Issuance patterns in the structured credit, asset-backed and riskier bond and loan markets underwent profound shifts in the years leading up to global financial crisis, notably in that securitization issuance volumes surged in the most complex, risky, and opaque market segments that had previously played only a peripheral role in the industry (Segoviano and others, 2013).

For instance, between 2000 and 2005, annual U.S. subprime mortgage issuance rose from $\$ 100$ billion to more than $\$ 600$ billion, lifting the subprime share of total U.S. mortgage origination from a low of 6.9 percent to a peak of 20.1 percent. These loans featured heavily in the explosive growth in collateralized debt obligations (CDOs). Over the same period, the rapid emergence of new and federally-unregulated players as a force in U.S. mortgage markets saw private-label residential mortgage backed security (MBS) issuance increase from $\$ 150$ billion to $\$ 1.2$ trillion, increasing their share of total MBS issuance from 18 percent to 56 percent. ${ }^{19}$ Between 2000 and 2007, global issuance of CDOs increased more than six times to $\$ 1$ trillion, while issuance of CDO-squared product increased eleven-fold to $\$ 300$ billion. Far from reflecting just a U.S. phenomena, between 2000 and the onset of the crisis, annual European securitization issuance increased from $€ 80$ billion to just over $€ 700$ billion. More broadly, other forms of high-risk debt issuance also increased markedly, notably high yield bonds, leveraged loans, covenant-lite loans, and payment-in-kind (PIK) notes (Figure 9). ${ }^{20}$

\footnotetext{
Traditionally, to the extent that non-price data has been examined in the context of asset bubbles, the focus has been almost exclusively on credit growth, dating back to at least Kindleberger (1978) and Minsky (1986, 1992). Yet credit growth can occur in ways that escape conventional measurement (especially in shadow banking), and moreover, bubbles might still present a major threat to financial stability even in the absence of leverage, particularly where their bursting drives risk premiums out to unusually wide levels that prohibit capital formation.

18 Related analysis of both price and quantity-based data appear in BIS (2012) and IMF (2014). In a more limited context, Stein (2013) examines the financial stability implications derived from patterns in credit issuance, while Feroli and others (2014) focus on investor fund flows.

19 More than 45 percent of high cost first-time mortgages were originated by independent mortgage companies that were not regulated by federal agencies (Bernanke, 2008).

20 PIK securities are a financial instrument that pay interest to investors in the form of additional debt or equity instead of a cash coupon. They are attractive to companies who need (or prefer) to avoid making cash outlays to investors. Cove-lite issuance refers to debt obligations which do not contain the usual protective covenants for the benefit of the lending party.
} 
Figure 9

The Pre-Crisis Boom in Risky Credit Issuance
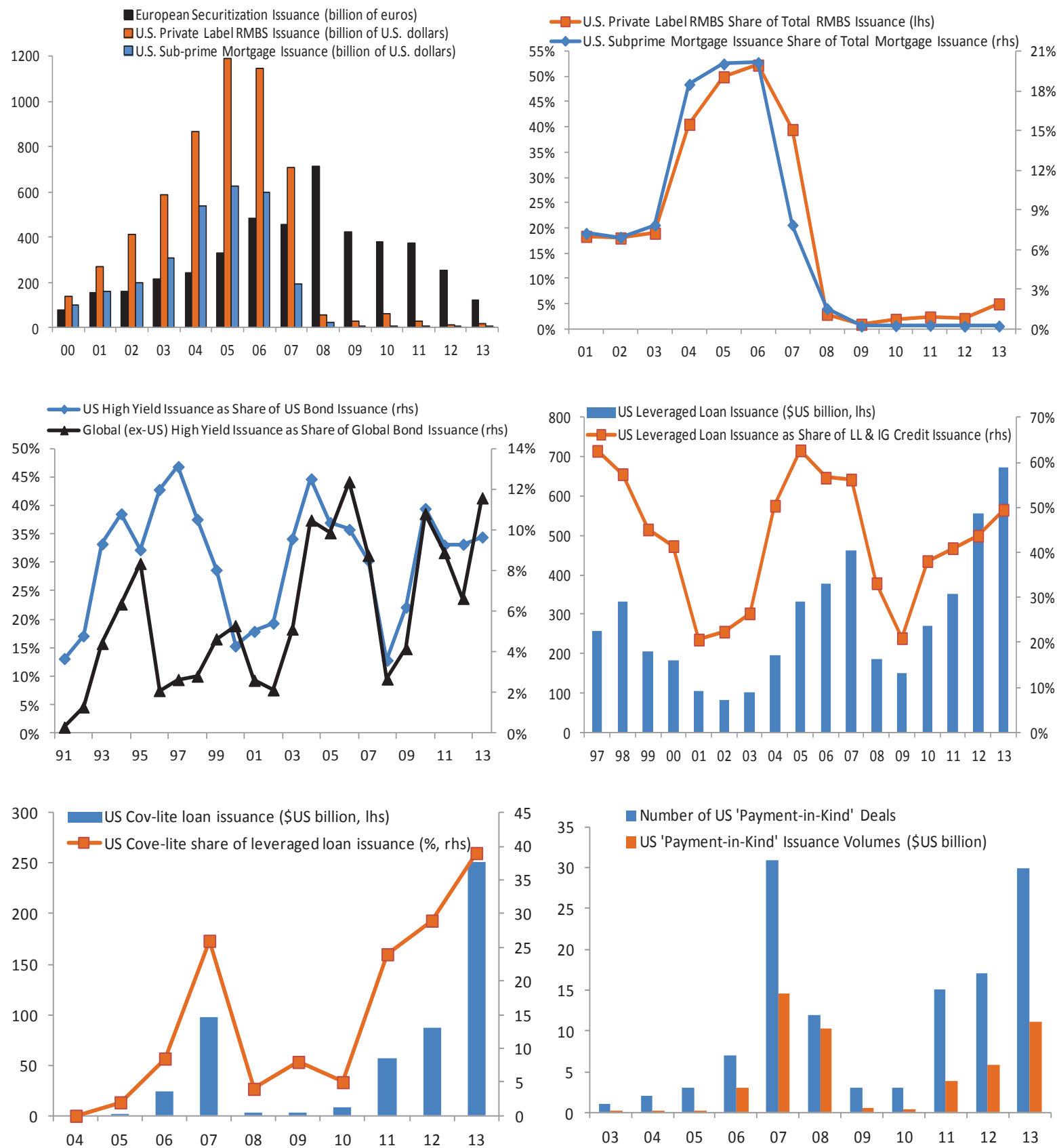

Source: Author's estimates, Inside Mortgage Finance, Dealogic, AFME, SIFMA,

Based on data back to the 1920s, Greenwood and Hanson (2013) establish that compositional shifts in the pattern of debt issuance between high and low quality firms, including the high yield share of total nonfinancial debt issuance, have had strong predictive power over future corporate bond returns (exceeding the explanatory power of spreads alone). A high and/or rising share of debt market issuance from lower quality firms can portend sharp credit spread widening episodes (Figure 10). As lower quality firms face binding financing constraints (unlike higher quality peers, they do not enjoy an indefinitely open window to raise capital), a relative flurry of lower quality debt issuance can signify unusually easy financing conditions and thus should be interpreted as an inherently procyclical development (Korajczyk and Levy, 2003). ${ }^{21}$ Similarly, in a study of the first high yield credit boom and bust cycle of the 1980s, Kaplan and Stein (1993) describe how the

21 A similar result holds for the debt and equity raisings of relatively small firms (Covas and den Hann, 2006). 
value of leveraged buyouts (LBOs) grew dramatically from just under \$1 billion in 1980 to over $\$ 60$ billion in 1988 (before collapsing below \$20 billion in the credit market bust of the following year). This growth was fuelled in part by the introduction of deferred or payment-in-kind interest features in high-yield bonds, which further reduced the protection of already junior creditors and was analogous to investors willingly accepting low or even negative ex-ante risk premia.

The implication from these findings is that policy makers need to go beyond simply monitoring the level of credit spreads or the growth in aggregate credit - the composition and quality of credit issuance may be even more important.

\section{Figure 10}

High Yield Share of Credit Issuance Before/After Credit Blow-ups

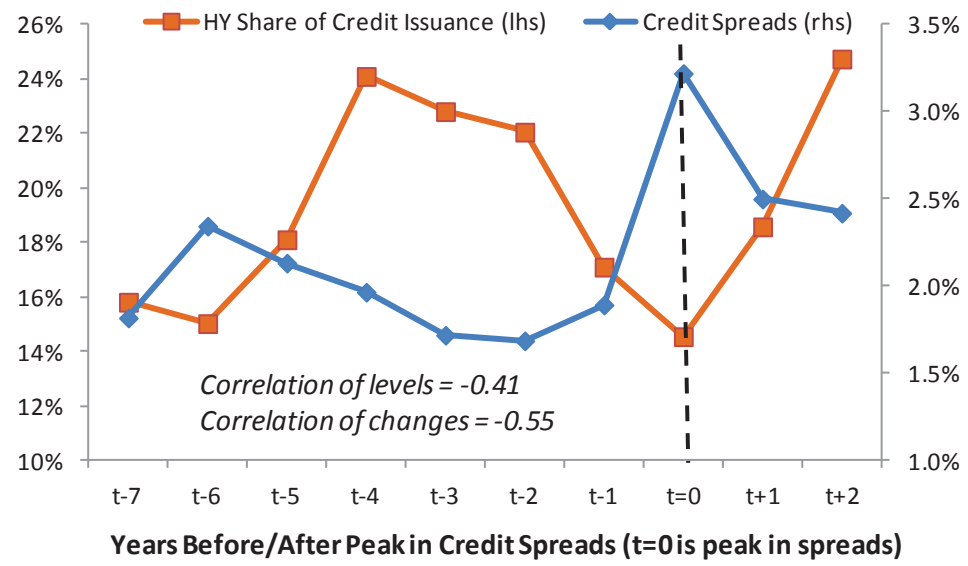

Source: Author's estimates, Greenwood and Hanson (2013).

Notes: Figures are based on an average of the ten largest annual BBB spread widening episodes between 1924 and 2016.

Drawing on the pecking order theory of Myers and Majluf (1984) where corporate managers ('insiders') exploit their informational advantages (in that they know more about the value of their firms than outsiders), patterns of equity issuance that accelerate into a large run up in stock valuations can also be of interest for financial surveillance purposes. Bernstein and Arnott (2003) show that the two largest booms (and busts) in U.S. stock market history- the late 1920s and late 1990 s — coincided with the fastest ever rates of aggregate U.S. net equity issuance. ${ }^{22}$ Nelson (1999) finds each percentage point of U.S. net share issuance is associated with a market that is 5 percent overvalued relative to historical averages. At the single stock level, inflated valuations have been found to be a key element of IPOs which helps to explain their subsequent long-run underperformance (Ritter, 1991; Schultz, 2003, Baker and Xuan, 2009). ${ }^{23}$ Since stock prices are positively correlated, and all firms are incentivized to issue equity when valuations are high, aggregate equity issues tend to cluster around market peaks (Korajczyk and others, 1990; Baker and Wurgler, 2000). Gilchrist and others (2004) show that as stock prices move well above measures of fundamental value, managers rationally respond by issuing new equity which has the effect of reducing the cost of capital and increasing the desire to invest. ${ }^{24}$ The corporate

\footnotetext{
22 The trend pace of net dilution was 5 percent in the late $1920 \mathrm{~s}$, and 3 percent of market capitalization in the late $1990 \mathrm{~s}$. The cyclically-adjusted price-earnings multiple peaked at 33 times and 47 times respectively.

23 Earnings manipulation has also been found to contribute to procyclical issuance at the single-stock level: companies issuing new stock tend to enjoy particularly good earnings and stock price performance prior to an offering, as earnings are managed upwards by incorporating all possible accruals into income. However the accelerating recognition of income simply borrows from the future. Investors fall into the frequent trap of extrapolating the good times to last indefinitely, only to be greeted with a sharp subsequent drop off in stock price performance (Loughran and Ritter, 1995, 1997; Teoh and others, 1998).

24 Neoclassical investment theories such as 'Tobin's Q' posit a direct, simple link between market valuation and investment decisions: firms invest when the increase in market value due to investment exceeds the costs.
} 
investment boom in the U.S. accompanying the late 1990s equity market bubble is a notable recent example. ${ }^{25}$

Based on U.S. data since 1965, Figure 11 illustrates the empirical link between an unusually low cost of capital, and elevated net equity issuance (gross issuance less gross buybacks) the following year. ${ }^{26}$ Drawing on the experience of the largest stock booms in the U.S., Germany, China and India, Figure 12 similarly shows that initial public offering (IPO) volumes tend to surge when the cost of raising capital (i.e. the required return for investors to hold stock) is unusually low. At the global level, the surge in the number (and value) of global IPOs was especially notably in the late 1990s. These observations reflect the notion that corporate managers are incentivized to issue securities when prices are unusually high relative to fundamentals. ${ }^{27}$ Collectively, the procyclical findings on debt and equity issuance suggest a role for policy makers to closely monitor changes in the quantity and composition of capital market financing.

Figure 11

U.S. Aggregate Net Equity Issuance vs. Equity Valuations

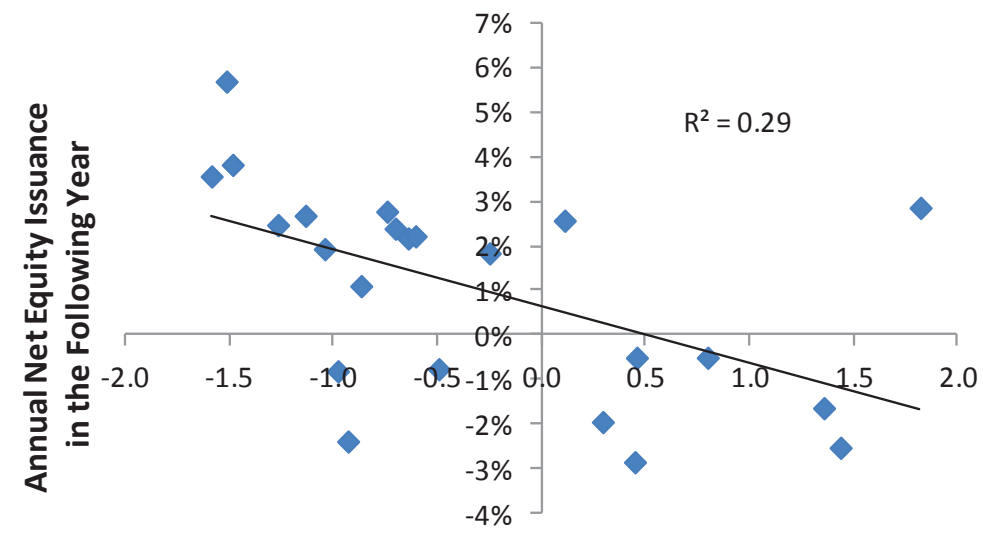

Risk Premia (\# of Std Deviations vs. Average) at end of Year

Source: Author's estimates, Haver.

Notes: Annual data based on the S\&P 500 from 1965- 2013. The regression measures the 'voluntary' equity issuance response (i.e. when real returns have been positive over the past five years) of corporate managers to different levels of risk premia (required return) in the stock market. The required return on stocks (an average of three model outputs, as defined in the Annex) is a statistically significant predictor (at the 1 percent level) of net equity issuance the following year.

5 From 1992 to 2000, the non-residential investment share of GDP rose from 8.5 to 13.2 percent (a record).

26 Capital raisings occurring around recessions, when valuations are depressed, are not of interest here.

27 In another illustration of the 'insider selling' concept, private equity management teams have also been found to invest a substantially smaller fraction of their net worth in post-buyout equity vis-à-vis pre-buyout equity: managers tend to "cash out" a large fraction of their pre-buyout equity investment at the time of the exiting buyout, and may therefore have an incentive to participate in overpriced exits (Kaplan and Stein, 1993). Kaplan and Stein (1993) also find that ahead of a downturn in company fortunes, financiers with the most intimate knowledge of deals such as relatively risk averse bank lenders and private subordinated debt financiers ('insiders') begin exiting while public subordinated lenders ('outsiders') increase their exposure. 
Figure 12

IPO Volumes vs. Stock Valuations in Equity Booms
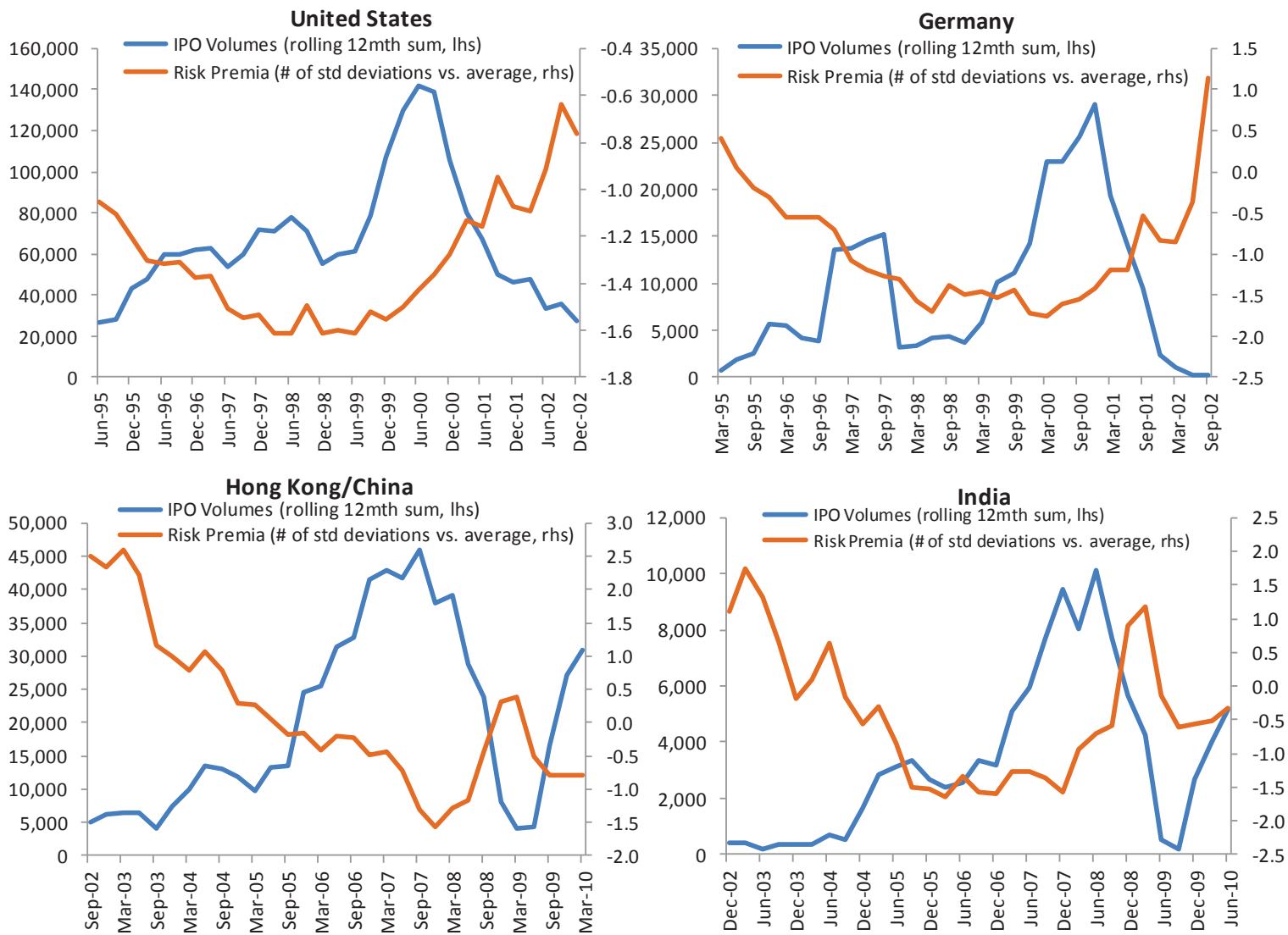

Source: Author's estimates, Dealogic.

Notes: IPO volumes in millions of \$US, shown 5 years prior to and two years after the peak in IPO volumes.

\section{(ii) Trading/Transaction Volumes}

Periods of unusually elevated trading activity may also have a role to play in surveillance work. Classical asset pricing theory suggests that where investors share the same beliefs and information, and perceive one another to be rational, the incentive to transact (at the expense of one another) would evaporate. As a result, trading activity would collapse to reflect only unanticipated liquidity and portfolio rebalancing needs of investors. However, these motives seem far too small to account for the enormous trading volumes observed in reality, most notably during periods of rapidly rising asset prices. Though trading volume is frequently relegated to a separate and effectively unconnected area of inquiry from studies of market efficiency, it is hard to imagine a fully satisfying asset pricing model - in either the rational or behavioral genres - that does not give a front-and-center role to trading volume (Hong and Stein, 2007). As Cochrane (2011, p. 1079) observes in a sweeping survey, "every asset price bubble - defined by popular use of the label — has coincided with a trading frenzy, from Dutch tulips in 1620 to Miami condos in 2006."28

Figure 13 displays the relationship between the growth in real stock prices and growth in trading volumes across a variety of equity markets during some the largest bull markets in history: the 'Roaring 1920s' episode, Japan's Heisei bubble in the late 1980s, the U.S. technology bubble in the late 1990s,

\footnotetext{
28 Kindleberger (2011, p. 15) likens speculative manias to a "frenzied pattern of purchases" reflected in rapidly rising trading volumes, a phenomena synonymous with the 'greater fool theory' whereby more and more euphoric investors purchase securities solely in anticipation of future short-term capital gains. For a related discussion of transaction volumes in the Dutch Tulip Mania, see Mackay (1841) and Garber (2001); for the South Sea stock bubble of 1720, see Carlos, Neal, and Wandschneider (2006); for the U.S. stock bull market of the 1920s, see Thomas and Morgan-Witts (1979) and Hong and Stein (2007); for a similar phenomena during the 1990s technology bubble, see Cochrane (2003) Scheinkman and Xiong (2003); Ofek and Richardson (2003); and Hong and others (2006).
} 
and China's equity boom in the mid-2000s. A similar pattern for transaction volumes unfolded in the case of the recent U.S. housing market bubble (see Figure 1). Average daily trading volumes in the U.S. mortgage backed security market increased five-fold in absolute terms between 2000 and 2008 (and doubled relative to lower risk Treasury and corporate bond markets), while high yield trading activity also rose sharply relative to investment grade credit trading activity prior to the crisis. ${ }^{29}$

Figure 13

Equity Trading Volumes Around Equity Market Booms (as a z-score)

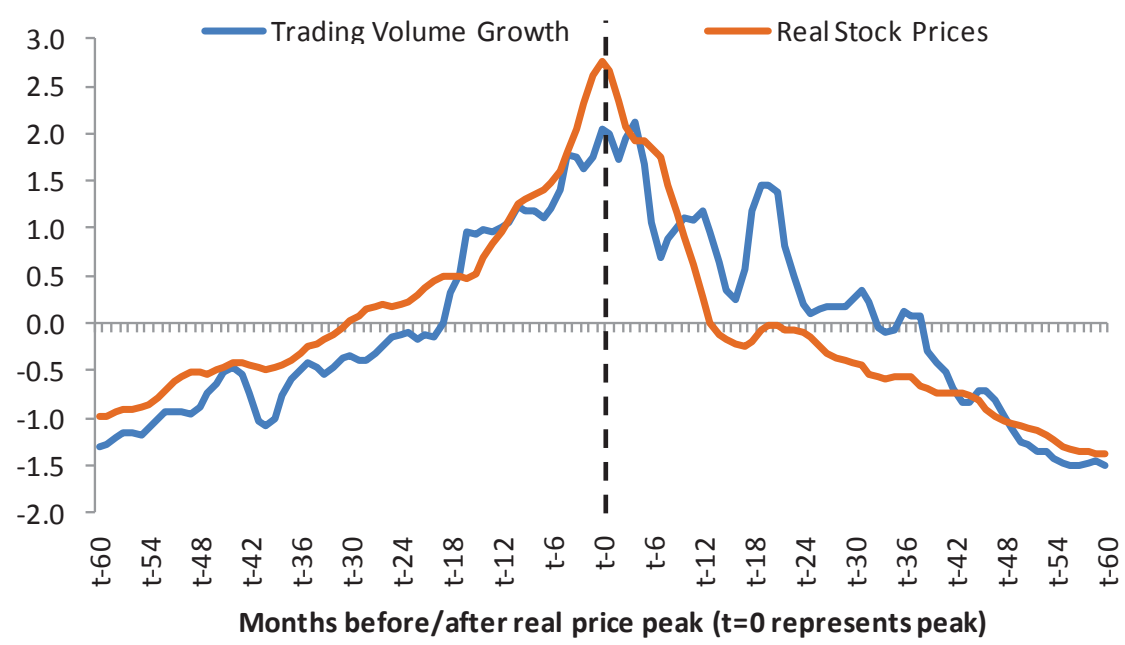

United States, $1924-1934$

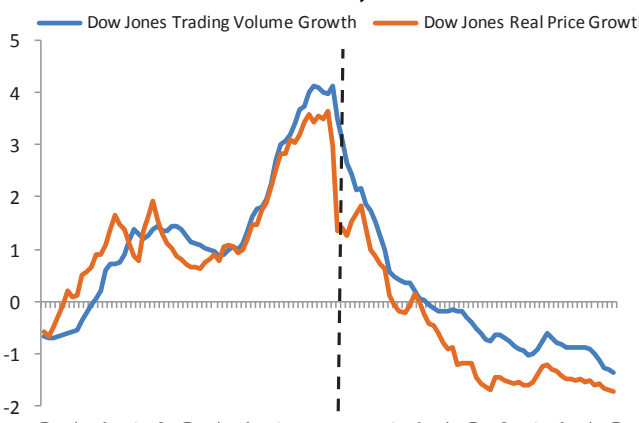

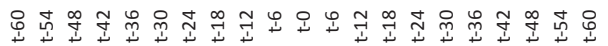

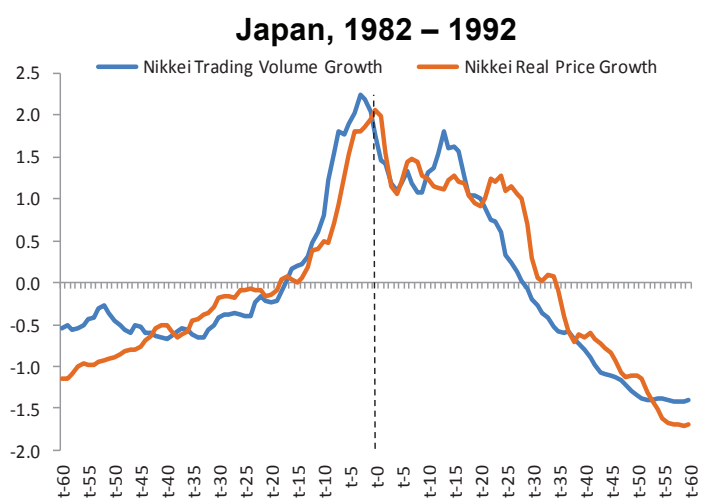

China, $2002-2012$

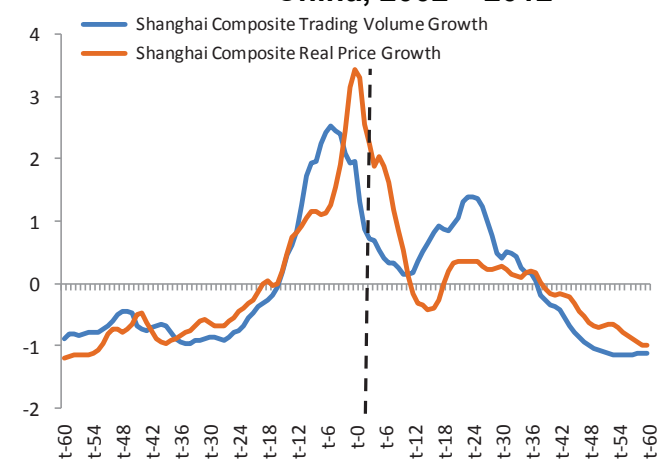

Source: Author's estimates, Bloomberg.

Notes: The top panel depicts the simple average z-score (depicting the number of standard deviations from the mean) for trading volume and real price growth (measured over five years) during the largest real price boom in the following 24 countries: Australia, Canada, Chile, China, France, Germany, Hong Kong, India, Indonesia, Italy, Japan, Korea, Mexico, Netherlands, Norway, Poland, Russia, Singapore, Spain, Sweden, Switzerland, Turkey, UK, and the U.S.

29 Hong and Sraer (2013) document "quiet bubbles" as a phenomena unique to high grade debt markets, as bonds have a smaller embedded resale option value than infinite-lived assets like stocks and housing, and hence have less disagreement, volatility, and turnover. 


\section{(iii) Investor Fund Flows}

Though cross-border capital flows have long featured in the literature on balance of payments crises, only in recent times have researchers begun to examine the financial stability implications arising from herding and redemption patterns in institutional investment funds. Elevated fund flows can put upward pressure on prices (particularly in small or illiquid asset classes), which in turn attract more flows from underinvested and/or underperforming investors (Chevalier and Ellison, 1997, 1999; Vayanos and Woolley, 2013; Jones, 2015). There are few natural circuit breakers to this feedback loop. The fund flows of unlevered investment managers operating in the 'relative performance derby' vis-à-vis their peer group can be a locus of financial instability to the extent they are motivated by herding considerations (Woolley, 2010; Cai and others, 2012; Feroli and others, 2014; Jones, 2015). ${ }^{30}$

The pattern of investor fund flows into and out of asset classes suggests they should be monitored by authorities. Investor fund flows (based on EPFR data) appear to gradually rise over a period of years and peak at around one standard deviation above average just prior to a large decline in asset prices (Figure 14). In the subsequent bust, cumulative fund flows fall to more than one standard deviation below average before markets trough.

\section{Figure 14}

Fund Flows in the Years Preceding a Bust (average z-score across asset classes)

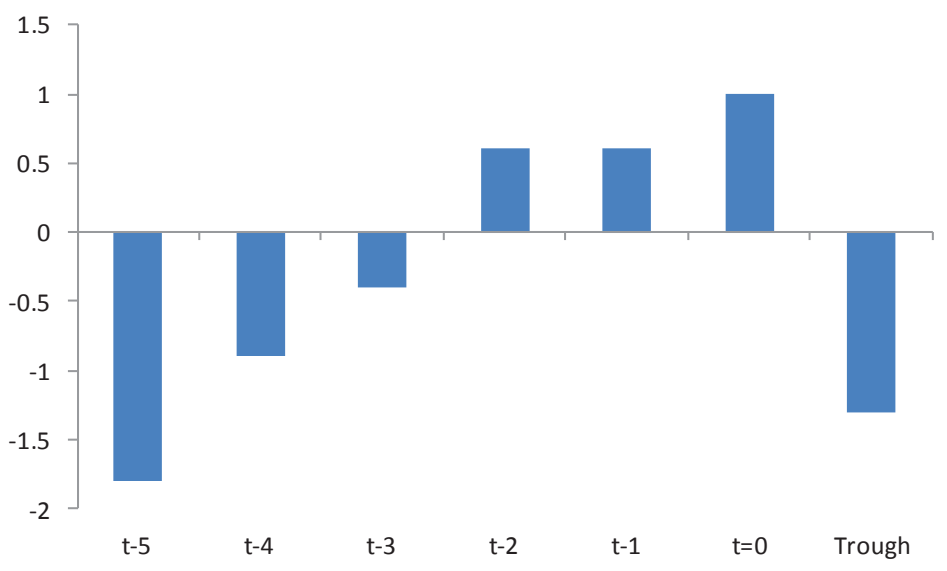

Source: Author's estimates, EPFR, Haver.

Notes: Average z-score (depicting the number of standard deviations from the mean) of cumulative three-year flows (normalized as a share of total fund assets) across developed market equity, emerging market equity, emerging market hard currency fixed income, emerging market local currency fixed income, global high yield credit, and U.S. Treasuries. A 'bust' is defined as the largest peak-to-trough decline in real returns for each asset class between 1996-2014 (or earliest available).

30 Positive feedback trading can result from no manager wanting to be last in or last out, with the effect most pronounced in relatively risky and illiquid markets. Chen and others (2010) show that redemptions from mutual funds holding illiquid assets create incentives like those facing depositors in a bank run (see the classic model of Diamond and Dybvig, 1983). Money market funds can face a particularly acute form of vulnerability to runs. 


\section{(iv) Surveys of Return Expectations}

\section{Figure 15}

Survey-based vs. Objective Measures of Future U.S. Stock Returns
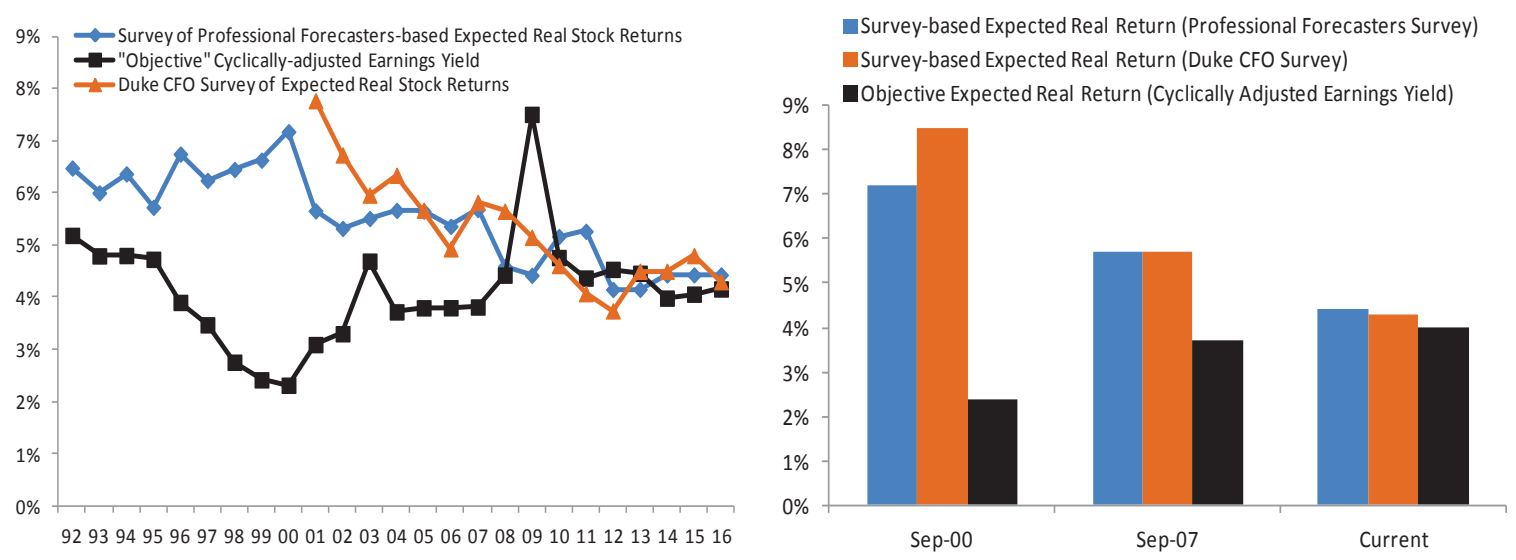

Source: Author's estimates, Duke Quarterly CFO Survey, Philadelphia Fed Survey of Professional Forecasters.

Notes: Latest estimates are as at Q1-2016. 'Objective' measure of future stock returns is the cyclically adjusted earnings yield calculated as the ratio of the ten-year moving average of earnings to stock prices.

To the extent they highlight the irrational extrapolation of past returns into investor estimates of future returns, survey data may also serve as another tool in the asset bubble surveillance toolkit. Shiller (2000b) developed a survey-based indicator to assess whether stock market investors were buying stocks purely on the basis of expectations of a short term increase in the market. Muellbauer (2012) argues that central banks should regularly survey home buyers regarding their expectations for capital appreciation for this express purpose, especially where there might be a large degree of uncertainty over model-based estimates of 'fair value' (as is typically the case for housing). Survey data reveal that after a run up in asset prices, subjective expectations of returns tend to be high while objective expected returns tend to be low (Ilmanen, 2011; Greenwood and Shleifer, 2013; Williams, 2013).

Unlike past cyclical highs in the U.S. stock market, survey-based estimates of expected returns appear relatively benign at the present time (as a relatively new field of research, lengthy time series of investor expectations for risky asset returns have been compiled only for the U.S. stock market). At the peak of the 1990s equity bubble, investor return expectations (as measured by the Survey of Professional Forecasters, and the Duke University CFO Survey) were around three times higher than the (objective) cyclically-adjusted earnings yield (Figure 15). Not only were return expectations high in the Duke CFO survey, they were also rising at the same time the earnings yield collapsed in response to booming stock prices. Just prior to the late-2007 market peak, survey-based return expectations were again rising and well above the earnings yield measure of future returns. 


\section{CONCLUDING REMARKS AND FUTURE RESEARCH}

The cost of bursting bubbles, and the inability of authorities to identify the accumulation of excesses in asset markets prior to the global financial crisis, suggests the need for an augmented surveillance framework. While acknowledging that the identification of asset bubbles will always remain a difficult task and require some element of subjectivity — a task that cannot be reduced to a single equation - the analysis presented in this paper suggests that a framework anchored in both price and non-price terms offers an encouraging starting point. Asset pricing models, no matter how elaborate, should be the place to begin, not finish, surveillance work. By measuring risk taking behavior, and financial vulnerabilities more generally, in ways that escape conventional asset valuation-based analysis, this paper argues quantity data offer a promising, complementary way to enrich our understanding of asset market dynamics.

The broader issue of what policy makers should do about asset bubbles, while beyond the scope of the present analysis, constitutes a critical related objective of future research. In the aftermath of the global financial crisis, much emphasis has been placed on the role of monetary and macroprudential policy in circumventing conventional leverage-driven asset booms. However, the dimensions of the next crisis will not necessarily follow those of the most recent cycle. Characteristics of the rapidly growing asset management industry-including incentives for asset managers to knowingly 'ride bubbles' - present policy makers with challenges that will likely require examination of a new suite of policy tools if authorities are to mitigate future threats to financial instability. In conjunction with ongoing analysis of early warning surveillance techniques, these areas should be fertile ground for future research.

\section{Acknowledgements}

The author is grateful for feedback from colleagues at the International Monetary Fund, in particular Tamim Bayoumi, Olivier Blanchard, Luc Everaert, Gaston Gelos, Shuntaro Hara, Tommaso Mancini-Griffoli, and Miguel Savastano; and for comments from seminar participants at the University of California's Center for Analytical Finance (Santa Cruz). The views expressed herein are those of the author alone and should not be attributed to the IMF, its Executive Board, or its management. The author has no conflicts to declare in support of the publication of this research.

\section{References}

Alessi, L., and Detken, C. (2009). Real time early warning indicators for costly asset price boom/bust cycles: A role for global liquidity. Frankfurt, Germany: ECB Working Paper Series, No. 1039.

Akerlof, G., and Shiller, R.J. (2009). Animal spirits: How human psychology drives the economy, and why it matters for global capitalism. Princeton, NJ: Princeton University Press.

Asness, C.S. (2014). My top 10 peeves. Financial Analysts Journal, 70(1), 22-30.

Baker, M., and Wurgler, J. (2000). The equity share in new issues and aggregate stock returns, The Journal of Finance, 55(5), 2219-57.

Baker, M., and Xuan, Y. (2009). Under new management: equity issuance and the attribution of past returns. Cambridge, MA: Harvard Business School Working Paper.

Bank for International Settlements. (2012). Operationalising the selection and application of macroprudential instruments. Basel, Switzerland: CFGS Papers, 48.

Bernanke, B. (2008). Fostering sustainable homeownership. National Community Reinvestment Coalition Annual Meetings, Washington DC.

Bernstein, W.J., and Arnott, R.D. (2003). Earnings growth: The two percent dilution. Financial Analysts Journal, 59(5), 47-55.

Black, F. (1986). Noise. The Journal of Finance, 41(3), 529-543. 
Bonner, W., and Rajiva, L. (2007). Mobs, messiahs and markets: Surviving the public spectacle in finance and politics. Hoboken, NJ: John Wiley \& Sons Inc.

Cai, F., Han, S., and Li, D. (2012). Institutional herding in the corporate bond market. Washington DC: Board of Governors of the Federal Reserve System, International Finance Discussion Papers, Number 1071.

Campbell, J.Y., and Thompson, S.B. (2008). Predicting excess stock returns out of sample: Can anything beat the historical average? Review of Financial Studies, 21(4), 1509-1531.

Campbell, J.Y., Lo, A.W., and MacKinlay, A.C. (1997). The econometrics of financial markets, Princeton, NJ: Princeton University Press.

Carlos, A., Neal, L., and Wandschneider, K. (2006). Dissecting the anatomy of exchange alley: The dealings of stockjobbers during and after the south sea bubble. Champaign, IL: Working Paper, University of Illinois.

Cassidy, J. (2010, January 13). Interview with Eugene Fama. New Yorker Magazine. Retrieved from: http://www. newyorker.com/online/blogs/johncassidy/2010/01/interview-with-eugene-fama.html.

Chancellor, E. (2000). Devil take the hindmost: A history of financial speculation. New York, NY: Farrar, Straus and Giroux.

Chen, Q., Goldstein, I., and Jiang, W. (2010). Payoff complementarities and financial fragility: Evidence from mutual fund outflows. Journal of Financial Economics, 97(2), 239-262.

Chevalier, J., and Ellison, G. (1997). Risk taking by mutual funds as a response to incentives. The Journal of Political Economy, 105(6), 1167-1200.

Chevalier, J., and Ellison, G. (1999). Career concerns of mutual fund managers. Quarterly Journal of Economics, $114(2), 389-432$.

Cochrane, J.H. (2003). Stock as money: Convenience yield and the tech-stock bubble. In W.C. Hunter, G.G. Kaufman, and M. Pomerleano (Eds.), Asset Price Bubbles: The Implications for Monetary, Regulatory and International Policies (pp. 174-201) Cambridge, MA: MIT Press.

Cochrane, J.H. (2011). Presidential address: discount rates. The Journal of Finance, 66(4), 1047-1108.

Covas, F., and den Haan, W.J. (2006). The role of debt and equity finance over the business cycle. Ottawa, Canada: Bank of Canada Working Paper 2006-45.

Diamond, D. and Dybvig, P. (1983). Bank runs, deposit insurance, and liquidity. Journal of Political Economy, 91(3), 401-19.

Fama, E.F. (1970). Efficient capital markets: A review of theory and empirical work. The Journal of Finance, 25(2), $383-417$.

Feroli, M., Kashyap, A.K., Schoenholtz, K., and Shin, H.S. (2014). Market tantrums and monetary policy. Working Paper presented at the 2014 U.S. Monetary Policy Forum, New York, NY. Retrieved from: http://research. chicagobooth.edu/igm/usmpf/2014.aspx?source=igm-em-usmpf14-20140221-initial.

Flood, R.P., and Garber, P.M. (1994). Speculative bubbles, speculative attacks, and policy switching. Cambridge, MA: MIT Press.

Fuller, R.J., and Hsia, C.C. (1984). A simplified common stock valuation model. Financial Analysts Journal, 40(5), 49-56.

Gallin, J. (2008). The long-run relationship between house prices and rents. Real Estate Economics, 36(4), $635-658$.

Garber, P. M. (2001). "Famous first bubbles: The fundamentals of early manias," The Journal of Political Economy, 109(5), 1150-1154.

Gerdesmeier, D., Reimers, H., and Roffia, B. (2009). Asset price misalignments and the role of money and credit. Frankfurt, Germany: ECB Working Paper Series, No. 1068.

Gilchrist, S., Himmelberg, C.P., and Huberman, G. (2004). Do stock price bubbles influence corporate investment. New York, NY: Federal Reserve Bank of New York Staff Reports, No. 177.

Greenwood, R., and Hanson, S.G. (2013). Issuer quality and corporate bond returns. Review of Financial Studies, 26(6), 1483-1525.

Greenwood, R., and Shleifer, A. (2013). Expectations of returns and expected returns. Cambridge, MA: NBER Working Paper No. 18686.

Gurkaynak, R.S. (2005). Econometric tests of asset price bubbles: Taking stock. Washington, DC: Finance and Economics Discussion Series, The Federal Reserve Board Working Paper 2005-04.

Haldane, A.G. (2014). The age of asset management? Speech at the London Business School, London. Retrieved from: http://www.bankofengland.co.uk/publications/Documents/speeches/2014/speech723.pdf.

Hamilton, J.D., and Whiteman, C.H. (1985). The observable implications of self-fulfilling expectations. Journal of Monetary Economics, 16(3), 353-373.

Harrison, M.J., and Kreps, D. (1978). Speculative investor behavior in a stock market with heterogeneous expectations. Quarterly Journal of Economics, 92(2), 323-336.

Hirshleifer, J. (1977). The theory of speculation under alternative regimes of markets. The Journal of Finance, 32(4), 975-999.

Hong, H., Scheinkman, S., and Xiong, W. (2006). Asset float and speculative bubbles. The Journal of Finance, 61(3), 1073-1117. 
Hong, H., and Stein, J.C. (2007). Disagreement and the stock market. Journal of Economic Perspectives, 21((2), 109-128.

Hong, H. and Sraer, D. (2013). Quiet bubbles. Journal of Financial Economics, 110(3), 596-606.

Ilmanen, A. (2011). Expected returns: An investor's guide to harvesting market rewards. Chichester, UK: John Wiley \& Sons Ltd.

International Monetary Fund. (2014). Global liquidity_issues for surveillance. Washington, DC: IMF Policy Paper. Jones, B. (2015). Asset bubbles: Rethinking policy for the age of asset management. Washington, DC: IMF Working Paper 15/27.

Kaminsky, G., Lizondo, S. and Reinhart, C. (1998). Leading indicators of currency crises. IMF Staff Papers, 45(1), $1-48$.

Kaplan, S., and Stein, J.C. (1993). The evolution of buyout pricing and financial structure in the 1980s. Quarterly Journal of Economics, 108(2), 313-357.

Keynes, J.M. (1936). The general theory of employment, interest, and money. New York, NY: Harcourt Brace.

Kindleberger, C.P. 1978 (2011). Manias, panics and crashes. New York, NY: Macmillan.

Kindleberger, C. (1987). Bubbles. In J. Eatwell, M. Milgate and P. Newman (Eds.), The new palgrave: A dictionary of economics. London, UK: MacMillan.

Korajczyk, R.A., and Levy, A. (2003). Capital structure choice: Macroeconomic conditions and financial constraints. Journal of Financial Economics, 68(1), 75-109.

Korajczyk, R.A., Lucas, D., and McDonald, R.L. (1990). Understanding stock price behavior around the time of equity issues. In R.G. Hubbard (Ed.), Asymmetric information, corporate finance and investment (pp. 257-277). Chicago, IL: University of Chicago Press.

Loughran, T. and Ritter, J.R. (1995). The new issues puzzle. The Journal of Finance, 50(1), $23-51$.

Loughran, T. and Ritter, J.R. (1997). The operating performance of firms conducting seasoned equity offerings. The Journal of Finance, 52(5), 1823-1850.

Mackay, C. 1841 (1852). Memoirs of extraordinary popular delusions and the madness of crowds. London, UK: Office of the National Illustrated Library.

Minsky, H. (1986). Stabilizing an unstable economy. New York, NY: Columbia University Press.

Minsky, H. (1992). The financial instability hypothesis. New York, NY: The Jerome Levy Economics Institute of Bard College Working Paper 74.

Muellbauer, J. (2012). When is a housing market overheated enough to threaten stability? In A. Heath, F. Packer and C. Windsor (Eds.), Property markets and financial stability (pp. 73-105). Sydney, Australia: Reserve Bank of Australia.

Myers, S.C., and Majluf, N.S. (1984). Corporate financing decisions when firms have information investors do not have. Journal of Financial Economics, 13(2), 187-221.

Nelson, W.R. (1999). The aggregate change in shares and the level of stock prices. Washington, DC: Board of Governors of the Federal Reserve System, Finance and Economics Working Paper Discussion Series 1999-08.

Ofek, E., and Richardson, M. (2003). Dotcom mania: The rise and fall of internet stock prices. The Journal of Finance, 58(3), 1113-1137.

Reinhart, C.M., and Rogoff, K.S. (2009). This time is different: Eight centuries of financial folly. Princeton, NJ: Princeton University Press.

Ritter, J.(1991). The long-run performance of initial public offerings. The Journal of Finance, 156(1), 3-27.

Scheinkman, J. and Xiong, W. (2003). Overconfidence and speculative bubbles. Journal of Political Economy, $111(6), 1183-1219$.

Schultz, P. (2003). Pseudo market timing and the long-run underperformance of IPOs. The Journal of Finance, 68(2), 483-518.

Segoviano, M., Jones, B., Lindner, P., and Blankenheim, J. (2013). Securitization: lessons learned and the road ahead. Washington DC: IMF Working Paper 13/255.

Siegel, J.J.(2003). What is an asset price bubble? An operational definition. European Financial Management, 9(1), $11-24$.

Shiller, R.J. (2000a). Irrational exuberance. Princeton, NJ: Princeton University Press.

Shiller, R.J. (2000b). Measuring bubble expectations and investor confidence. The Journal of Psychology and Financial Markets, 1(1), 49-60.

Shiller, R. J.(2003). Diverse views on asset bubbles. In W. C. Hunter, G. G. Kaufman, and M. Pomerleano (Eds.), Asset Price Bubbles: The Implications for Monetary, Regulatory and International Policies (pp. 35-40). Cambridge, MA: MIT Press.

Sobel, R. (1968). Panic on wall street. New York, NY: Macmillan.

Stein, J.C. (2013). Overheating in credit markets: origins, measurement, and policy responses. Restoring household financial stability after the great recession: Why household balance sheets matter. St. Louis, MO: Federal Reserve Bank of St. Louis. 
Stein, J.C. (2014). Incorporating financial stability considerations into a monetary policy framework. Washington, DC: Board of Governors of the Federal Reserve System, Remarks at the International Research Forum on Monetary Policy.

Stiglitz, J.E. (1990). Symposium on bubbles. Journal of Economic Perspectives, 4(2), 13-18.

Teoh, S.H., Welch I., and Wong, T.J. (1998). Earnings management and the underperformance of seasoned equity offerings. Journal of Financial Economics, 50(1), 63-99.

Thomas, G., and Morgan-Witts, M. (1979). The day the bubble burst. New York, NY: Doubleday \& Company.

Vayanos, D. and Woolley, P. (2013). An institutional theory of momentum and reversal. Review of Financial Studies, 26(5), 1087-1145.

Welch, I., and Goyal, A. (2008). A comprehensive look at the empirical performance of equity premium prediction. Review of Financial Studies, 21(4), 1455-1508.

Williams, J. (2013). Bubbles tomorrow and bubbles yesterday, but never bubbles today? Speech to the National Association for Business Economics,San Francisco, CA. Retrieved at: http://www.frbsf.org/our-district/press/ presidents-speeches/williams-speeches/2013/september/asset-price-bubbles-tomorrow-yesterday-never-today/.

Woodford, M. (2003). Interest and prices. Princeton, NJ: Princeton University Press.

Working, H. (1962). New concepts concerning futures markets and prices. American Economic Review, 52, $431-459$. 


\section{ANNEX \\ Estimates of Required/Expected Returns}

Throughout the paper, the terminology 'expected' or 'required' returns is applied to the valuation of housing and stock markets (both of which are real assets with an undefined maturity that can be modeled as a perpetual running yield), while 'excess returns' refer to corporate bond spreads and risk premia in the government bond markets (i.e. nominal assets with a fixed maturity). Valuation estimates are derived as follows:

- Housing - constructed as a quarterly index of the ratio of rents to home prices. ${ }^{31}$ The rental series is the 'rent of primary residence' published by the Bureau of Labor Statistics. Nominal home price data are based on the series published in Shiller (2000a), with updates available in Haver.

- Stocks - expected real returns (into perpetuity) are defined as an equally weighted average of three models for the real discount rate backed out of current prices: ${ }^{32}$

(i) The cyclically-adjusted earnings yield, defined as the reciprocal of the ratio of prices to the seven year moving average of annual earnings per share for the MSCI country indices (aside from the longer U.S. series, which is based on S\&P500 data back to 1914 from the Robert Shiller website);

(ii) The forward-looking single stage Gordon growth dividend model, where: Price $=$ dividend per share / (long-term bond yield + equity risk premium - long term GDP growth). Prices, (cyclically adjusted) dividends, and the long-term risk free rate can be directly observed. Long-term inflation and real GDP growth expectations are based on survey data reported by Consensus Economics beginning in 1989. Prior to this, expectations for nominal growth are proxied by the 10-year moving average of inflation and real GDP growth.

(iii) The forward-looking multi-stage 'H-model' of Fuller and Hsia (1984), where the growth rate of earnings per share in the first seven years is based on matching year GDP growth expectations, with an upward or downward adjustment based on the current level of profit margins so as to stabilize the profit to GDP ratio in the steady state. A constant (60 percent) payout ratio is applied to (cyclically adjusted) earnings to ameliorate crosscountry differences in dividend taxation policies. The yield curve out to seven years is used to discount the initial set of cash flows. Cash flows beyond seven years are modeled as a constant growth-rate perpetuity based on long-term growth and inflation expectations, and long term bond yields. Using observable spot prices, the pricing equation is solved iteratively such that observed market prices are consistent with future cash flows and discount rates. Long-term inflation and real GDP growth expectations are based on survey data reported by Consensus Economics from 1989. Prior to this, expectations for nominal growth are proxied by the 10-year average of inflation and real GDP growth.

- Credit - for U.S. investment grade bonds, duration matched spreads are based on the difference between Moody's seasoned Baa and Aaa bond yield series available via the St Louis Federal Reserve FRED service. For high yield bonds, duration-matched spreads are derived from the Bank of America Merrill Lynch BB+ corporate bond yield series available from Global Financial Data, and US Treasury bond yields.

- Government Bonds - motivated in part on Woodford (2003), the 'Wicksellian' bond risk premium is defined as the spread between the 5 year 5 year forward bond yield, and the equilibrium (or neutral) rate, which is proxied by long term consensus expectations of real

31 Gallin (2008) finds the rent/price ratio to be useful for forecasting future U.S. home prices.

32 Welch and Goyal (2008) and Campbell and Thompson (2008) run a series of horse races for competing models of equity valuation. Although not the primary purposes of this paper, like these studies, it was difficult to find any specification which could rival the forecasting power of the simple cyclically-adjusted earnings yield, despite it containing no forward looking inputs. 
growth and inflation over the same period (a negative Wicksellian risk premium suggests bond yields are too low relative to the neutral rate, as proxied by long-run estimates of growth and inflation). This is essentially a special case of the Taylor rule for the bond market, where the neutral rate is captured by long term consensus expectations of real growth and inflation, and the inflation and output gap are closed. Wherever possible, zero-coupon bond yields are used (in their absence, the yield to maturity).

Finally, real GDP growth and inflation expectations are measured out to ten years via a survey of professional forecasters compiled by Consensus Economics. These data, though not entirely free of limitations, are interesting from a number of perspectives: they are not subject to revisions or serious time lags as is the case for many macrofinancial time series routinely employed in studies of asset price predictability; they are available on a consistent cross-country basis; and they can capture market expectations of structural breaks or changes in macro variables, upon which estimates of fundamentals are based. To the best of the author's knowledge, this is the first time such data have been used in a comparable study. 